\title{
The Role of Institutional Context for Sustainability Cross-Sector Partnerships. An Exploratory Analysis of European Cities
}

\author{
Eduardo Ordonez-Ponce
}

check for updates

Citation: Ordonez-Ponce, E. The Role of Institutional Context for Sustainability Cross-Sector Partnerships. An Exploratory Analysis of European Cities. Sustainability 2021, 13, 9497. https://doi.org/10.3390/su13179497

Academic Editor: Ermanno C. Tortia

Received: 16 July 2021

Accepted: 18 August 2021

Published: 24 August 2021

Publisher's Note: MDPI stays neutral with regard to jurisdictional claims in published maps and institutional affiliations.

Copyright: (C) 2021 by the author. Licensee MDPI, Basel, Switzerland. This article is an open access article distributed under the terms and conditions of the Creative Commons Attribution (CC BY) license (https:// creativecommons.org/licenses/by/ $4.0 /)$.
Faculty of Business, Athabasca University, Athabasca, AB T9S 1A5, Canada; eduardo.ordonez@athabascau.ca; Tel.: +1-844-250-5021

\begin{abstract}
Institutional contexts influence structures and processes of any organizational system. Most of the research on cross-sector partnerships (CSSPs) has focused on their internal performance, methods, and effectiveness; however, the institutional contexts that allow or inhibit their development have been limitedly assessed. Many local CSSPs address sustainability issues, and this research explores Barcelona + Sustainable's and Bristol Green Capital Partnership's institutional contexts at the local, national, and international levels. Interviews were conducted with the leaders of the partnerships and responses were assessed using Scott's (1995) institutional pillars. Findings show the cultural-cognitive and normative institutional elements of context as the most relevant for local sustainability CSSPs, with regulatory elements not existing at the national level nor cultural-cognitive at the international scale. More importantly, results highlight trust, diversity, communication channels, sense of place, changing perceptions, and coopetition as key learnings to be considered for other partnerships in their design. Finally, with cultural-cognitive and normative elements speaking of the power of local features, it is these partnerships the ones influencing others beyond their scopes of action, with the potential of leading sustainability even further. However, associated activities and resources to provide stability and meaning to sustainability partnerships must be satisfied for that to happen.
\end{abstract}

Keywords: institutional contexts; cross-sector partnerships; sustainability; partner organizations; institutional pillars

\section{Introduction}

Sustainability is a grand challenge [1] that requires the involvement of organizations from all sectors [2]. Implementing cross-sector social partnerships (CSSPs) is one way to address sustainability challenges [2], collaborative initiatives that require the active participation of different partners for their success [3,4]. However, although CSSPs focused on sustainability at the local level have increased in numbers [5], the contexts under which they are implemented have been limitedly understood.

Contexts are key in the development and success of organizations [6], with institutional contexts as crucial elements in the development and attainment of organizational goals [7]. From a contingency perspective, organizations must tailor their structures conforming to the challenges they face to succeed [8] because these set the conditions for organizations to operate [6]. However, contexts are not only environmental, but interactions between external and internal variables influence organizations [9]. Furthermore, institutional contexts, such as socio-cultural, economic, and political variables, influence structures and processes of any organizational system [10]. However, while most of the research on CSSPs has been directed to their internal performance, methods, and effectiveness [11,12], or the partners' institutional logics [13] or strategic approaches [5,14,15], the institutional contexts that allow or inhibit the development of CSSPs have not been largely assessed.

Partnerships are not independent initiatives, but they coexist with others in a determined place and time with which they share a common context formed by regulations, 
rules, norms and a shared history that influence their development. While the importance of favourable institutional contexts is recognized as a factor of successful collaboration $[3,16]$, unfavourable contexts could inhibit the success of partnerships. These settings in which CSSPs are designed and implemented, where they develop and succeed or fail, have been poorly studied [17], as well as how CSSPs and institutional contexts relate to each other [18]. This exploratory research aims to contribute to filling in that gap through the study of large CSSPs that engage many diverse partner organizations, which are crucial for addressing sustainability goals [19], but have still been limitedly studied [20,21].

Many cities address sustainability issues through partnerships [22,23], and this research studies two large CSSPs: Barcelona + Sostenible $(B+S)($ Name in Spanish. Sostenible = Sustainable in English), and the Bristol Green Capital Partnership (BGCP). Both partnerships have worked for more than fifteen years with around one thousand organizations from across sectors in addressing topics such as poverty, water, climate, and employment. Barcelona aims to be more equitable, prosperous, and self-sufficient [24], and Bristol's goal is to be a thriving low-carbon city; with a circular economy; with food that is good for its people, places, and the planet; and a nature-rich city where everyone can travel sustainably [25]. B $+\mathrm{S}$ works through a strategic plan led by the municipality renewed every ten years, with a clear action plan with indicators and goals [24]. BGCP aims to achieve its goals towards 2050 through collaborative projects supporting its vision and mission, a process that is managed by a community interest company with a board of directors formed by organizations from all sectors $[25,26]$.

While national institutional contexts are fundamental in the enhancement of strong institutions [27-29], local institutional contexts where B + S and BGCP are focused on have not been deeply studied. This research explores the local, national and international institutional contexts that enable and inhibit the development of $\mathrm{B}+\mathrm{S}$ and BGCP to understand the settings under which these sustainability partnerships flourish. To achieve this purpose, an institutional approach has been taken using the three pillars of institutions proposed by Scott [30] and the partnerships' leaders interviewed.

This paper is structured as follows. First, the understanding of contexts, institutional contexts and cross-sector partnerships are set. Then, methods are presented including the case studies, measures and data collection and analysis, being followed by results and a discussion section.

\section{Literature}

\subsection{Context}

Sustainability is about change and innovation for addressing society's most pressing challenges [31], with context as an active component [6] influencing organizations [7,9]. Context has been studied through different approaches. The phenomenological approach argues that context is a complex phenomenon socially constructed, unquantifiable, and not easily assessed, which needs to be understood through the assessment of power relations among actors [6]. The psychological perspective sees context as a mental concept created by humans to which organizations adapt [32], while the positivist approach sees it as a reality that can be observed and measured, which possesses determined features with which organizations interact and which set their boundaries of action $[6,33]$.

While implementing change, organizations must deal with inner and outer contexts. Inner contexts refer to the structure, culture, history and political variables that shape organizations; while outer contexts are about the social, economic, political and competitive environments under which organizations operate [6]. Under this rationale, context refers to the important role that place plays in the interactions between organizations and institutional factors [7], an institutional context that strengthens and preserves organizational features [10]. As an example, ethical consumption practices and discourses are embedded in places [34], with contextual factors as keys to understanding social, economic and developmental complexities [35]. 


\section{Institutional Context}

Institutional context is defined as a set of rules and practices that affect and frame social processes [34], a shared system of ideas that preserves a determined condition [36]. Institutional contexts refer to the settings of established and shared rules and conditions under which organizations operate [37], which set the boundaries and conditions of interaction between organizations and the environment.

Institutional logics are characterised by "formal and informal rules of actions, interactions, and interpretations that guide, constrain, and are shaped by action" as organizations function in their respective social systems [33]. While the term 'institutional thickness' refers to a strong institutional manifestation, with high level of interactions and cultural norms and values shared among actors [37], 'institutional voids' is about the lack of functioning institutions [35] that would provide the support that organizations need to operate and interact with other contextual actors [27].

Institutional theory has been largely used to address sustainability and CSR-related topics in connection to institutional contexts [18,28,38-40], and for studying social partnerships $[13,17,33]$. Based on the logic that institutional contexts influence the way organizations operate [16,28], the three pillars of institutions proposed by Scott [30] have been used to understand institutional pressures $[28,40,41]$ and are the framework used in this research. According to Scott [30] "Institutions comprise regulative, normative, and cultural-cognitive elements that ... provide stability and meaning to social life", highlighting them as "vital" ingredients of institutions. The regulative pillar is about coercive processes that set rules, monitor performance, and sanction activities to influence behaviour [30,42]. The normative pillar comprises normative rules introducing a "prescriptive, evaluative, and obligatory dimension into social life", including values, norms, and roles [30,42]. Values refer to what is preferred or desirable; norms to how things should be done, giving legitimacy to valued ends; and roles to goals and activities assigned to particular individuals [30]. Additionally, the cultural-cognitive pillar includes symbols and "symbolic processes ... that work to construct social reality, to define the nature and properties of social actors and social actions" [30].

Scholars studying institutional factors and their relationships to different stakeholders identify the state as a central element of national institutional contexts [34,38,43]. National institutional contexts play a key role in the enhancement of local 'institutional thickness' [37] through its political, financial, educational and cultural systems [27,28], driving sustainability reporting [18], influencing how effective corporate governance structures are in adopting sustainability [40], and stakeholder engagement practices [44]. Furthermore, institutional factors are crucial in the development of partnerships $[45,46]$ with macro and micro national factors conditioning the decision to start a CSSP and configure it according to a determined purpose [33,47]. Table 1 shows some of the main institutional factors organised according to Scott's institutional pillars, recognising that they form a continuum from strict regulations to unconscious behaviours [30], which can interact and overlap with each other [10,28].

Table 1. Institutional factors according to the three pillars of institutional structures.

\begin{tabular}{ll}
\hline Institutional Pillars [30] & Institutional Factors \\
\hline & The state $[29,34,38,48]$ \\
& The government/Political system \\
& {$[10,18,27,28,34,35,38-40,43,48-50]$} \\
& The market/economic and financial environment \\
& {$[10,27,38-40,43,44,48-50]$} \\
Regulatory & Law, regulations, and policies $[10,18,28,38-40,44,49]$ \\
& Judicial system $[10,18,28,38-40,44,49]$ \\
& Social institutions $[18,27,38,43,49]$ \\
& International regulations $/$ pressures $[28,44]$ \\
\hline
\end{tabular}


Table 1. Cont.

\begin{tabular}{ll}
\hline Institutional Pillars [30] & Institutional Factors \\
\hline & Accreditations [6] \\
& Informal rules: conventions, norms of behaviour, codes of \\
& conduct, expectations, social norms, values, beliefs \\
& {$[3,7,10,28,34,35,38,40,44,48-50]$} \\
& Peer pressure: industry norms, institutionalised norms, \\
& professional networks [28,38-40,43,44,49] \\
& International organisations [44] \\
& Civil society: consumer groups, communities, constituency \\
& groups, society in general, etc. [27,28,39,40,43,44,49] \\
The press [10,44] & Educational systems [40,50] \\
& Labour systems and trade unions [39,50] \\
& Governments [28] \\
& Culture [7,9,10,18,28,34,38,40,43,50,51] \\
& History [9,10,34,50] \\
& Relationships, networks [9,38] \\
& Geographical location [34,43] \\
& Religion [18,35] \\
& Language [43] \\
Social institutions [18,28,34,43] & Symbols: words, signs, and gestures [28,40] \\
Customs [18,35,38] \\
\hline
\end{tabular}

\subsection{Cross-Sector Partnerships}

Partnerships are institutional arrangements responding to changes happening in their respective contexts that contribute to shaping societal governance [52]. They have been defined as "collective strategies" focused on a common vision with explicit agreements among partners [53]. This logic denotes a "pluralistic approach" involving diverse stakeholders who collaborate with their resources to attend to societal problems representing an option to "state-centric" endeavours led by governments [54].

With societal relationships becoming more dynamic and society facing growing uncertainty, social-focused partnerships have blossomed worldwide $[19,55]$, seeing them as a way to meet and accomplish socio-environmental goals $[2,56]$. Considering that sustainability issues such as water scarcity, energy efficiency or unemployment are grand and complex challenges to be tackled by any organization alone [56,57], it is imperative to involve actors from all sectors in partnerships to achieve sustainability [2,56]. CSSPs are an alternative for companies to meet their socio-environmentally responsible conducts, cut down their environmental footprint and boost their image; for not-for-profits to be more competent and accountable, adopting tasks that public organizations are not realising; and for governments to arrange more aid, whilst enhancing transparency $[55,56]$.

Since CSSPs focus on societal issues, they place partners in the public realm, demanding their active engagement by committing their means to the preparation, organization, assessment and development of activities identified as required for the realization of partnerships [4]. CSSPs stand "in the midrange of how organizations work on public problems", in between organizations barely interacting with others and those that have blended into new bodies that seek to create public value not created by solo partners [57].

Four types of CSSPs exist. Some are led by governments in collaboration with companies and not-for-profits; others are formed by businesses and the public sector, or between companies and civil society organizations, and others are between the public sector and civil society organizations [54,56]. Some involve many and diverse partners from the private, public, and civil society sectors, and others are small with up to three partners from different sectors [58]. 


\subsection{Sustainable Communities}

The concept of sustainable development became highly relevant after the United Nations World Commission on Environment and Development's report from 1987 "Our Common Future", which proposed a new form of development that integrates economic development, social equity, and environmental degradation $[59,60]$. Then, as a way to lead the implementation of sustainable development at the local level, the UN launched Local Agenda 21 (LA21) in 1992, urging local governments to enter "into a dialogue with [their] citizens, local organizations and private enterprises" [61]. LA21 is "a participatory, multi-sectoral process to achieve the goals of [the global] Agenda 21 at the local level through the preparation and implementation of a long-term, strategic action plan that addresses priority local sustainable development concerns" [62].

Since then, thousands of communities have adopted strategic sustainability plans of some kind all over the world [22,23], taking different forms based on their goals, needs, and priorities [23]. However, as authorities are not capable of achieving sustainability alone $[4,57]$, these are being designed and implemented in partnership with many actors from across sectors as key players in the path to local sustainability [2,56]. Strategic community sustainability plans include collective sustainability visions $[63,64]$, plans of action, targets, indicators and deadlines to which partner organizations commit. In general, community sustainability plans focus on social, economic, and environmental issues, including unemployment, economic development, quality of education $[4,56]$, health care, poverty alleviation, environmental issues [56], climate change, corruption, organized crime [2], waste, air, energy, land use, transportation, and housing [65]. As seen later in this article, the selected partnerships for this study have detailed sustainability plans.

Following this rationale, several perspectives around sustainable cities and communities have emerged worldwide. For example, the concept of creative cities refers to how culture would help in the creation of new urban images, making cities more attractive to capital and workers [66], arguing that the knowledge economy requires creative cities capable of combining concentration, diversity, instability and a positive image [67]. Although creative cities is a concept that has been associated to the development of cities for years, current research shows a growing interest in connecting it to the creative class and culture, and on understanding creative clusters and networks [68].

Another related concept is that of smart cities, which approaches cities through a technological lens where digital technologies merge with traditional infrastructure in a coordinated and integrated manner [69]. However, this was how smart cities were understood in the 1990s [70]. Nowadays, a smart city is much more than just the application of technology to cities. It is about advanced cities that connect people, information, and their services using technology to create greener, competitive, and innovative cities with a good quality of life [71]. Smart cities aim to create more habitable urban centres [72], where investments in people and infrastructure would enhance economic growth thanks to a sustainable management of natural resources and participatory governance [73]. Smart cities are also known as intelligent or digital cities [70]. One of the differences between smart and sustainable cities is the emphasis of the former in economic and social dimensions over environmental aspects [74].

At the end, despite their differences, it can be argued that all of these approaches aim to achieve sustainable cities, as proposed by LA21. A sustainable city is one that achieves "a balance between the development of the urban areas and protection of the environment with an eye to equity in income, employment, shelter, basic services, social infrastructure and transportation" [75] whose "conditions of production do not destroy over time the conditions of its reproduction" [76]. As a result, the success or failure of a community in achieving sustainable development will be subject to "continuously adjusting to meet its social and economic needs while preserving the environment's ability to support it" [77]. 


\section{Methods and Results}

For purposes of this exploratory study, a constructivist approach has been considered relying as much as possible on the participants' views of the studied phenomena, using questions allowing interviewees to construct meanings and the researcher to make sense of it [78]. Following this worldview, methods have been designed and implemented to achieve the purpose of this article.

\subsection{Case Studies}

Under the constructive view, this article uses qualitative case studies as a bounded system with a clear purpose $[79,80]$ that is characterized by its relationships with context [79]. In particular, this research focuses on the specific cases presented by CSSPs that aim to contribute to the sustainability of cities [80], basing its analysis on the observations of key stakeholders [79].

Following the literature, this research uses the institutional pillars proposed by Scott [30] as a theoretical framework, moulding the research questions that gave shape to the interviews $[79,80]$. However, an inductive approach was developed when interviewing by openly presenting questions so they were not restricted by Scott's pillars [81,82]. Then, during the analysis of the interviews, these were assessed according to the framework, but room was left for potential categories to come up from the findings.

With respect to sampling, a long process led to the purposive selection of $B+S$ and the BGCP. Purposeful sampling is one of the steps of research design proposed by Merriam (1998) that together with conducting a literature review, constructing a theoretical framework, identifying the research problem, and designing research questions are key in qualitative research [83]. As a widely used technique in qualitative research for identifying and selecting cases that provides rich information with limited resources [84], B + S and BGCP and their leaders were identified and invited to participate based on their knowledge and experience with the phenomenon of interest [85], availability, willingness to participate, and on their capacities to communicate properly [86].

Previous research conducted by the author and colleagues around CSSPs started with a list a more than 100 international partnerships implementing sustainability plans in diverse cities from which a subset of those having many partners from across sectors was identified. Large partnerships have still not been studied enough $[5,20]$, they continue increasing in numbers $[19,22]$ and have been recognized as key for achieving sustainability goals $[21,87]$. Then, the selected large CSSPs were classified according to their plan time horizon as we wanted to study long-term partnerships so the interested variables could be properly assessed [15], which is also appropriate to study institutional contexts. Then, we aimed for CSSPs affecting between one and two million people from developed countries as that would relate to the partnership size, the diversity of their sustainability challenges and having more budget to address them [88]. These figures refer to the geographic area of impact of the partnerships, which go beyond the boundaries of the respective cities. Finally, four CSSPs were studied $[5,15,21]$ and from there B + S and BGCP were selected for this exploratory research as the ones best suited to contribute to this study (Table 2).

Table 2. Selected cross-sector partnerships.

\begin{tabular}{cccccccc}
\hline CSSP & $\begin{array}{c}\text { Total } \\
\text { Partners }\end{array}$ & $\begin{array}{c}\text { Private } \\
\text { Sector }\end{array}$ & $\begin{array}{c}\text { Public } \\
\text { Sector }\end{array}$ & Civil Society & $\begin{array}{c}\text { Current } \\
\text { Timeframe }\end{array}$ & $\begin{array}{c}\text { Population } \\
\text { (Millions) }\end{array}$ & $\begin{array}{c}\text { Some } \\
\text { Recognitions }\end{array}$ \\
\hline B + S & 1200 & 448 & 396 & 356 & $2002-2020$ & $1.6[89]$ & {$[90-92]$} \\
BGCP & 950 & 523 & 48 & 380 & $2003-2050$ & $1.1[93]$ & {$[94-96]$} \\
\hline
\end{tabular}

\subsubsection{Barcelona + Sostenible $(B+S)$}

Barcelona has focused on sustainability topics at least since 1995, when it signed the Aalbörg Charter [24], formally starting its commitment to adopt its Local Agenda 21 
(LA21) by implementing long-term sustainability programs [97]. Then, and after prolonged discussions and consultations with representatives from all sectors [98], Barcelona drafted its LA21 in 1998 [99]. Barcelona's LA21 was led by The Municipal Council for the Environment and Sustainability, whose functions were to "formulate proposals, build consensus and take responsibility for results" [98]. That first stage led to working groups on thirteen sustainability topics, with the aim of diagnosing and developing action proposals and monitoring indicators [98]. These results were presented to the citizens in 2000 for consultation and brought back to the council for action [98]. Thereafter, lines of actions were established for the decade 2002-2012 under "The People's Commitment towards Sustainability" [100]. That initial commitment helped to the achievement of $100 \%$ of wastewater being treated, the consumption of water was reduced, and the use of solar energy grew dramatically [24]. This first public commitment was revised and renewed in 2012 and documented under the "Public Commitment towards Sustainability 2012-2022" with new goals and lines of action [99], based on the principles of shared responsibility and citizen participation [100]. This current pledge focuses on biodiversity; public spaces and mobility; environmental quality and health; efficiency, productivity, and zero emissions; rational use of resources; good governance and social responsibility; well-being; progress and development; education and citizen action; and resilience and planetary responsibility [24]. Each focus is developed through ten areas of action including the development of green corridors, the improvement of water quality, reduction of food waste to zero, encouragement of healthy lifestyles, and the eradication of poverty [24].

Barcelona has a population of more than 1.5 million people, which has decreased $7 \%$ since 1981, 80\% are over 25 years old, with one-third having a university degree [101]. Its main economic areas are services; commerce and repairs; education, health and social services; ITC; and hospitality [102]. Barcelona's GDP reaches $€ 31,000$ per capita [103], with an unemployment rate of $9.4 \%$ [104] and 9.2\% of poverty [105]. Barcelona is one of the most attractive cities for international (7th) and R\&D investment (4th) [106], the leading European city for FDI strategy, sixth in connectivity [107] and one of the cities driving most capital invested in tech in Europe [108]. Barcelona is among the safest cities in the world [109] and a leader in water savings [102]. The Sustainable Cities Index places Barcelona in the 28th position, 22nd in environmental sustainability, 24th in social sustainability, and 47th in economic sustainability [110]. Barcelona is one of the 100 Resilient Cities and C40 Cities [111,112] (Figures pre-COVID).

The current pledge of $\mathrm{B}+\mathrm{S}$ is the guideline for Barcelona, engaging more than 1100 organizations from all sectors (37\% from the private sector, $61 \%$ from the civil society, and $2 \%$ from the public sector) partnering to accomplish their proposed objectives [113]. While several goals have been achieved by Barcelona, the city still has challenges to advance its current conditions towards climate change adaptation improving its energy balance, reducing pollution levels, re-naturalizing the city and conserving biodiversity, reducing waste and increasing recycling, and decreasing private motor vehicles [114].

\subsubsection{Bristol Green Capital Partnership (BGCP)}

The City of Bristol is among the greenest of the United Kingdom [96], and the BGCP is " ... [one of] the largest partnership of its kind in the world" [115], with more than 1000 partner organizations from across sectors (59\% from the private sector, 36\% from the civil society, and 5\% from the public sector) working towards the achievement of its goals [26].

In the year 2000, local organizations gathered intending to transform Bristol towards a sustainable state, a process that led to the development of its Community Strategy, setting out a common vision to become "a green capital in Europe-creating sustainable communities and improving the quality of life" [115]. In 2007, Bristol Green Capital Partnership was founded to achieve the vision inviting organizations to make Bristol a "low-carbon city with a high quality of life" through partnering with cross-sector organizations [115]. The partnership started under the leadership of the Environment Agency and the Bristol City 
Council, local businesses and NGOs, the University of Bristol, and then more organizations followed [115].

Bristol signed the Covenant of Mayors in 2009 committing to reduce energy consumption by $30 \%$ and $\mathrm{CO}_{2}$ emissions by $40 \%$ by 2020 , and $80 \%$ by 2050 (baseline 2005) [96]. BGCP has developed several projects over the years, including transport, energy efficiency and renewable energy plans, dropping its carbon emissions consistently since 2005, with a growing economy and good air quality [96]. Initiatives such as these led Bristol to become the 2015 European Green Capital [94].

Since 2014, the partnership is being managed by a Community Interest Company (CIC) with a small staff team and governed by a board of independent and elected directors [115]. As of 2019, BGCP is financially supported by eleven members, including the Bristol City Council, which makes the largest financial contribution to the running costs. Currently and under the vision of an Environmentally Sustainable Bristol, the partnership focuses on five topics: energy, food, nature, resources, and transport, with specific goals, visions, links to the SDGs, and key areas for action towards 2050 [25].

Bristol has a population of more than 460,000 people [116], with an annual growth rate of 1.1\% [117]; however, partnership members such as Low Carbon South West CIC and the University of Bath are from beyond the limits of the city, so the partnership impacts a population of over one million people [93]. Bristol has more children than retirees, and $16 \%$ of the population belongs to a minority ethnic group [116]. Bristol's economy is strong with a GVA growth of 2.4\% between 2016 and 2019 and a forecast growth in GVA/head of $1.5 \%$ for the period 2020-2023 [118], with the second-largest number of start-ups among British core cities [119], an employment rate of 79\% [117], and an average income per capita of $£ 28,000$ [119]. However, inequality is still a challenge [120]. Almost $20 \%$ of children live in low-income families, with $11 \%$ of households experiencing fuel poverty, more than 40,000 people are food insecure, almost $8 \%$ of $16-17$ year olds are either not studying, being trained, or working [119], and $4 \%$ of population under working age has no formal qualifications [117]. Bristol is the 9th city with the most number of patents in the UK [117], it is the most artistic city and a UNESCO creative city of film, with around 20,000 jobs in creative and digital industries [119].

Bristol is a low-carbon hub of industry, with commitments to clean transport and energy [121]. Bristol emits about $10 \mathrm{~kg}$ of $\mathrm{NO}_{2}$ / people and 1.2 kilos of PM2.5 per capita, the former mainly from the transport industry and the latter from domestic, commercial and institutional fuel combustion [117]. The city council has dropped its emissions from direct operations by more than $76 \%$ since 2005, aiming to reach net-zero carbon by $2025, \mathrm{CO}_{2}$ emissions have decreased a third and per capita emissions by almost half [119]. In 2019, $46 \%$ of household waste was reused, recycled and composted with $86 \%$ of people stating to be concerned about climate change [119]. According to the Sustainable Cities Mobility Index, Bristol ranks 43rd, 63rd in the people sub-index, 21st in the planet sub-index, and 47th in the profit sub-index [122]. Bristol is part of the 100 Resilient Cities program [111]

\subsection{Measures}

A questionnaire was designed and focused on the partnerships' institutional contexts at three levels: local, national, and international. This selection is based on what the literature indicates about diverse contexts $[7,28,34]$ and the diversity of organizations partnering for local sustainability [5]. Local level refers to the city and community where the sustainability foci of the partnerships are on, national level is about the country or state which the cities or communities are part of, and international level means the international agenda potentially influencing the partnerships. Since the researcher has developed an academic relationship with the partnerships over the last years, he is capable of identifying those who would provide quality information through effective interviews $[79,80]$.

Six questions formed the questionnaire. The first asked about the local institutional conditions of context allowing the development of the partnerships; the second referred to the national elements of institutional context; and the third to the international elements 
as supported by the literature and partnerships' diversity. Then, and with the aim of contributing not only to identifying elements of institutional context, but also to make the most out of the ones helping partnerships and manage those playing against, two more questions were designed. The fourth question asked which institutional elements at all levels are the main enablers for the development of the partnerships, and the fifth focused on the elements that need to be revised to enhance the development of the partnerships. Although CSSPs focused on local sustainability have increased in numbers [19] and are recognized as crucial to achieve sustainability [21], they are certainly not perfect [123-125] and their impact remains an open question. Hence, these questions aim to contribute to the improvement of sustainability partnerships by highlighting the elements of context that should be positively considered as well as identifying those that may need to be managed properly so that they do not negatively affect the development of partnerships. Finally, a sixth question asked about learnings that can be shared from the experience of the partnerships at the different institutional contexts with the purpose of contributing to the development of other sustainability partnerships.

The interviewees were the main leaders of the partnerships, both with great experience and knowledge on their respective CSSPs and contexts. The leader of $\mathrm{B}+\mathrm{S}$ has been working at the Municipality of Barcelona for over 12 years always connected to the department where the partnership is based on and leading $B+S$ for most of that time. The leader of the BGCP joined the partnership almost three years ago and worked in other organizations for the sustainability of Bristol before, helping on her understanding of the institutional contexts. While leading their respective partnerships, which involves not only managing the partnerships' operations, but also engaging partner organizations and interacting with other key stakeholders from across sectors, they also participate in other initiatives for the sustainable development of their cities.

Since Barcelona and Bristol use two different languages, a source-to-target protocol for translating the questionnaire was used to ease potential translation bias [126]. The questionnaire was designed in Spanish by the researcher and a colleague knowledgeable of the topic, and then it was translated by both researchers into English, which is their working language [127]. The translation process was based on an Ask-the-Same-Question model so that the translation maintained the intended measurement properties [128]. The interviews were conducted over Skype, one in Spanish in August 2019 and the other in English in January 2020, lasting both one hour and twenty minutes on average. The interviews were transcribed into their original languages and then qualitatively analysed using NVivo by a third researcher with expertise in CSSPs whose mother tongue is Spanish and the working language is English. The interviewees revised their interviews and returned them with some minor adjustments validating the transcriptions. Then, a coding procedure was implemented according to the defined institutional levels, consolidating, reducing and interpreting what the interviewees had said, a process that resulted in a matrix that included the questions versus the partnerships. Finally, the findings from the cases were compared and commonalities and differences were determined.

\subsection{Data Analysis}

\subsubsection{Case 1: Barcelona + Sostenible}

\section{- Local institutional context}

As part of the local institutional context, the leader of $B+S$ refers to the existence of norms of participation that work as a positive framework to develop initiatives between the different partners, highlighting that these norms have been in place for a long time and are regularly updated. These norms work for the partnership, with a particular focus on the operationalisation of the municipal council and the partner organizations. The norms are part of a regulatory framework led by politicians through policies.

Related to sustainability, the commitment of Barcelona to LA21 and the existence of norms of participation allowed the creation of the Municipal Council for Environment and Sustainability with specific and regulated mechanisms. The norms and the committee 
allow the existence of clear and transparent frameworks of participation, with political representatives as visible faces of the council with several participatory processes that are also regulated through norms.

Another aspect of the local institutional context is the municipal administration and the municipal government, which support the partner organizations contributing to a solid partnership leading to the empowerment of the partners.

According to the interviewee, regulations, norms of participation, the initial commitments assumed by the city in 1995, and the increasing involvement of the partners have influenced the development of the institutional context and the dynamics of the partnership, as well as the willingness of the partners to contribute to the city's sustainability.

- National institutional context

At the national level, Barcelona is the capital of the autonomous province of Catalonia in Spain and the city in the province with the most resources. Barcelona is the sustainability leader in Catalonia collaborating with other municipalities in the province and the neighbouring Basque Country. No national policies have had any impact on the development of local policies in Barcelona.

- International institutional context

At the international level, two main issues are highlighted that are based on two distinct and distant moments: the decision made by the city Mayor in 1995 to sign the Aalbörg Charter and how this was crucial to adopt European commitments around sustainability and LA21, and the importance of the SDGs as a relevant framework for partner organizations. The United Nations Global Compact has also contributed to the development of initiatives in the private sector as a social responsibility framework.

- Main institutional enablers

When asked about the main institutional elements of context enabling the development of the partnership, the leader of B $+\mathrm{S}$ mentioned willingness in general, and political willingness in particular, which translate into adopting concrete actions. Open participation of citizens was identified by the leader as another main enabler, especially the political willingness to listen to the citizens and incorporate their concerns into the political agenda. Norms of participation were also mentioned as relevant, which relate to permanent consultation processes as a way to collect feedback from citizens beyond election periods. Although it was not directly asked of the interviewees, these elements seem to be highly related to local and somehow national institutional contexts.

- Main institutional elements that need to be revised

All kinds of resources were the main elements mentioned by the leader of $B+S$, particularly financial resources and time to relate and engage with partner organizations. Other elements mentioned include the need to improve sustainability norms, change to municipal bylaws, budgets, the implementation of subsidies, and significant changes to sustainability policies that should include economic, social and environmental challenges. Larger teams to develop the initiatives and support the partners, and larger investments to be able to implement the proposed policies were also highlighted. As an example provided by the interviewee, research conducted on a circular economy project shows that while most of the budget was focused on managing resources, a very limited team was dedicated to strategy and the creation of a circular economy culture. Furthermore, they argued that resources are needed not only to manage projects, but also to have time to reflect and decide how to make significant changes to the local culture. Similar to the identified institutional enablers, these elements seem to be identified at the local and national scale, which could be explained based on the role of the interviewees and of the partnerships.

- Learnings and relationships

According to the leader of $B+S$, some of the learning experiences speak to the importance of working shoulder to shoulder with the partners and trust-building, which 
result in a successful experience, allowing to keep a trustful building relationship with and among partners. Another dimension clearly mentioned was the need for honesty and clear rules of operation to keep trust bonds among partners, making explicit differences and grey zones.

Another learning experience highlighted by the leader of $\mathrm{B}+\mathrm{S}$ is the value of diversity within the partnerships, which is related to the organizations involved, the people working in the partnership, and the implemented strategies. According to the interviewee, diversity helps different stakeholders to get engaged since they feel represented in the partnership, which enriches the process and creativity increasing the chances of success. The leader argues that a key is being aware of the existing diversity and manage it properly. In this same context, the interviewee mentioned appropriate communication means within partners, between and among similar partners such as enterprises talking to other enterprises are crucial, so messages can be clearly understood and reliable partners met. Therefore, while diversity is an asset for creative processes, when concrete initiatives are implemented, according to the leader of $\mathrm{B}+\mathrm{S}$, it is recommended to work with similar ones whom partners can understand better and whose approaches they validate.

\subsubsection{Case 2: Bristol Green Capital Partnership}

\section{- Local institutional context}

The institutional context of BGCP is based on "a sense of place", which speaks to Bristol's citizens who are characterised by individuality and flair and thinking differently, who describe Bristol as "vibrant, diverse and friendly" [129]. These particular features are due to the social and cultural characteristics of Bristol, which refer to challenging environmental degradation, social inequality and justice. This is reflected in the actions implemented by organizations that align their programs with environmental principles creating a good foundation for the partnership's work. Particularly, the partnership's work is enabled by proactive organizations, including the Bristol City Council and many businesses based in Bristol, reflecting the city's culture in being led by ethical, environmental and sustainability principles. This culture-at times collaborative and at others willing to challenge-creates a good foundation for the partnership.

The local institutional context is based on voluntary initiatives and not on regulations. These voluntary activities are reflected in recommendations, such as the document "Our Future", which is the collective sustainability vision of the partnership for the city, and "Going for Gold" that supports the coordination of activities around food systems and individuals, as well as organizations and food businesses that want to make a shift. BGCP's approach is to amplify, enable, and share learnings from proactive steps taken by the members that benefit environmental sustainability and equality.

Another local institutional element mentioned is how the partnership works together, a "movement" that is changing the city, so the benefits of being in the partnership are not transactional, instead, it is a commitment from organizations across sectors that want to be part of a change benefitting all members. According to the leader of BGCP, this movement is enhanced thanks to the engagement of active individuals who engage their organizations and others from different sectors in the changing process.

There is a strong membership structure with almost a thousand members from all sectors who are engaged in different capacities, and 11 supporting members that financially contribute to the partnership. This structure makes the partnership very accessible, with collaborations happening across sectors involving a combination of leadership and the ability to influence their own operations and show commitment towards creating the conditions for sustainability to flourish in the city.

- National institutional context

At the national level, there have not been policies nor regulations influencing the partnership. BGCP is ahead in goals at the national level, so they would not have a major impact on Bristol. For example, Bristol aims to be carbon neutral by 2030, and the country is 
planning to achieve that goal by 2050, so the national targets have not necessarily supported progress, since Bristol is approaching environmental issues more urgently than the national authority. However, the national dialogue has been rapidly shifting since the BBC, a key media outlet in the UK, has started covering climate change impact stories more regularly, contributing to understanding the climate challenges that Bristol and the UK are facing. Furthermore, the BBC and key figures such as Sir David Attenborough are very close to people's national identity, influencing the national perspective on the issues the partnership is addressing.

At the regional scale, BGCP collaborates sharing information with other neighbouring authorities such as North Somerset Council and Bath and Northeast Somerset, trying to link its work with what is happening at the West of England Combined Authority. There has not been any sharing of resources nor funding joint initiatives.

- International institutional context

At the international level, the SDGs are the framework that helps to address sustainability, setting an educational agenda for partner organizations.

- Main institutional enablers

According to the leader of $\mathrm{BGCP}$, public opinion affects business contacts and regulations, enabling political leadership and advocacy. What deeply has enabled the development of the partnership is that Bristol was recognised with the European Green Capital Award in 2015, which contributed to Bristol's identity as a sustainability leader, argues the interviewee. According to the leader of $\mathrm{BGCP}$, the European award brought learnings and criticisms of approaches to environmental issues and awareness of the partnership. While this main institutional enabler comes from an international context, its effect was felt locally influencing local actors.

- Main institutional elements to be revised

Something that needs to be addressed, argues the interviewee, is part of the history of Bristol, and it is embedded in its social structure. The interviewee explains what they refer to as follows

Bristol ... has a history ... very much built on the slave trade, and we still have social divisions in the city, social inequalities... And one thing that was criticized about the European Green Capital year was that it wasn't as reflective of all of Bristol's communities as it could have been. And that plays into the age-old concern that ... and the perceptions around environmental sustainability being a white middle-class pursuit for people with leisure time and money to spare ...

As stated by the leader of $\mathrm{BGCP}$, the priority of $\mathrm{BGCP}$ is on environmental equality and the partnership tries to change people's perceptions since people in all parts of Bristol and regardless of ethnic backgrounds are worried about the impacts of climate change. Bristol must credit the work developed by different communities towards environmental sustainability, stated the interviewee. To address this issue, the partnership has started by changing the composition of its board making it more diverse reflecting the demographics of Bristol, and its planning to implement this approach through its activities. Although not asked directly to the interviewee, these elements are identified at the local scale.

- Learnings and relationships

According to the leader of BGCP, some of the learning experiences are around taking advantage and being aware of the strongly rooted sense of place and civil memory existing in Bristol, the history of the city, and how it has led to where it is now. While these are beneficial for the partnership, they also bring challenges to be addressed, highlighted the interviewee.

A main challenge is to change perceptions in demonstrating that sustainability is relevant to all people in Bristol, stated the leader of BGCP. This leads to helping communities to build resiliency to face the challenges that will come with climate change and 
potential regulations. Moreover, as Bristol is a leader in sustainability, according to the interviewee, they have pushed the boundaries in other communities, using the term coopetition to explain the dynamic that exists between leading cities, encouraging each other to adopt more challenging targets and test innovative policies, with outcomes beneficial for all communities.

\section{Summary of Results}

Results are organised according to the questions and the three levels of institutional context, the enabling elements, those that require a review, and the learnings.

\subsection{Local Institutional Context}

B + S identifies norms as a framework to develop formal collaborative initiatives that are sustainability-focused (normative elements), the willingness of partners and politicians to engage and commit to the partnership, and Barcelona's history (cultural-cognitive elements), which speak to its commitment to sustainability since 1995. BGCP highlights the relevance of the social and cultural characteristics of Bristol, which relate to the community's memory and sense of place, one of Agnew's [130] fundamental aspects of place (cultural-cognitive elements). These local features affect the existence of voluntary initiatives to contribute to the city and collaborative commitments across sectors with key individual actors (normative elements), all forming part of the local institutional context of Bristol. Additionally, B $+\mathrm{S}$ refers to their environment council, as a regulatory institution of formal control implemented to lead the partnership's actions, and BGCP draws attention to the importance of its structure formed by actors from across sectors (regulatory elements).

\subsection{National Institutional Context}

Among the features of national institutional context identified by $\mathrm{B}+\mathrm{S}$ are that it is a national leader that collaborates with other cities towards sustainability (cultural-cognitive and normative elements). Regulatory elements were not identified, since there are no national policies nor regulations contributing to the development of B + S. Similarly, in the U.K. there are no regulations nor policies impacting the development of BGCP. Bristol is also a leader that shares information with its peers throughout the southwest of England (cultural-cognitive and normative elements). At the national level, the media plays a normative role.

\subsection{International Institutional Context}

Regulatory and normative elements are the ones highlighted as part of the international institutional contexts of both partnerships. In particular, they recognise the United Nations as the international organization leading the sustainability agenda through pressure and informal rules [30], which are represented through the SDGs, and the Global Compact guidelines for business in Barcelona.

Table 3 presents a summary of the findings around Scott's institutional pillars at the three studied levels. Table 4 shows the main institutional enablers and elements that need to be revised as stated by the leaders of B $+S$ and BGCP, and Table 5 the learnings shared by the interviewees.

Table 3. Scott's institutional pillars to institutional contexts' levels.

\begin{tabular}{llll}
\hline & Cultural-Cognitive & Normative & Regulatory \\
\hline \multirow{2}{*}{ Local } & $\begin{array}{l}\text { Partners' willingness to } \\
\text { engage and commit; the } \\
\text { cities' history, culture, } \\
\text { customs, and informal rules. } \\
\text { The cities' customs, } \\
\text { culture and history. }\end{array}$ & $\begin{array}{l}\text { Norms of behaviour, codes } \\
\text { of conduct, and partners' } \\
\text { and society's expectations. }\end{array}$ & $\begin{array}{l}\text { Regulations and } \\
\text { policies, governance } \\
\text { mechanisms and } \\
\text { partnerships structure. }\end{array}$ \\
& $\begin{array}{l}\text { Collaborations with other } \\
\text { National }\end{array}$ & $\begin{array}{l}\text { Norms of behaviour, codes } \\
\text { of conduct, and partners' } \\
\text { and society's expectations. }\end{array}$ & Not identified \\
& Not identified & $\begin{array}{l}\text { The Aalbörg Charter, } \\
\text { SDGs, Global Compact. }\end{array}$ & The Aalbörg Charter, \\
International & & &
\end{tabular}


Table 4. Institutional enablers and elements to be revised.

\begin{tabular}{ll}
\hline Main Institutional Enablers & $\begin{array}{l}\text { Main Institutional Elements That Need to } \\
\text { Be Revised }\end{array}$ \\
\hline - $\begin{array}{l}\text { Willingness in general and particularly } \\
\text { political willingness towards adopting } \\
\text { concrete actions }\end{array}$ & $\begin{array}{l}\text { Resources in general and financial } \\
\text { resources in particular and time for the } \\
\text { partnerships to relate and engage with } \\
\text { partners. Larger teams and investments }\end{array}$ \\
$\begin{array}{l}\text { Open participation of citizens and } \\
\text { political willingness to listen to citizens } \\
\text { and incorporate their concerns }\end{array}$ & - $\begin{array}{l}\text { Improvement of sustainability norms, } \\
\text { bylaws, budgets, subsidies and economic, } \\
\text { Norms of participation and permanent } \\
\text { consultations processes }\end{array}$ \\
$\begin{array}{l}\text { Public opinion that affects business } \\
\text { contacts, regulations, political leadership } \\
\text { and advocacy }\end{array}$ & - $\begin{array}{l}\text { Addressing history and how it is } \\
\text { embedded in social structure }\end{array}$ \\
International recognition (awards) & $\begin{array}{l}\text { Inclusion of all, crediting the work } \\
\text { developed by many across } \\
\text { the community }\end{array}$ \\
\hline
\end{tabular}

Table 5. Main learnings.

\begin{tabular}{|c|c|}
\hline$B+S$ & BGCP \\
\hline $\begin{array}{ll}\text { - } & \text { Trust } \\
\text { - } & \text { Diversity } \\
\text { - } & \text { Communication }\end{array}$ & $\begin{array}{ll}- & \text { Sense of place } \\
\text { - } & \text { Changing perceptions } \\
\text { - } & \text { Co-opetition }\end{array}$ \\
\hline
\end{tabular}

\section{Discussion and Further Research}

Favourable institutional contexts are key factors in the success of partnerships [3], with institutions comprising "regulative, normative and cultural-cognitive elements that, together with associated activities and resources, provide stability and meaning to social life" [30].

As seen from the results, the cultural-cognitive, normative and regulatory pillars support the local institutional contexts of the selected sustainability partnerships, with regulatory elements not identified at the national level nor cultural-cognitive at the international scale. The relevance of all the pillars at the local level certainly is expected considering the partnerships' local foci. Somehow, the partnerships' focus on the sustainability of their cities creates a closed system where all the institutional elements converge, which from a practical perspective seems to be favourable as all the identified sustainability challenges are somehow geographically bounded and under a single system, with important exceptions to highlight such as the impact of climate change. This is certainly reflected in the sustainability plans designed and under implementation by the partnerships and their partners, which are the base under which sustainable cities are strategically designed. From a theoretical perspective, this shows that Scott's pillars framework can be applied to assess closed systems and determine the role that they play in their development.

However, cultural-cognitive and normative pillars are identified as the main institutional features at the local level for both partnerships. This speaks first to the sense of place, which is reflected in the public pressure and expectations from society with respect to the aims of the partnerships. Secondly, it refers to the voluntary condition of joining partnerships for local sustainability, a commitment based on local traditions and expectations where national regulations do not necessarily have a role to play. Furthermore, some of the identified learnings (e.g., trust, communication, sense of place, and coopetition) also relate to the partners' commitment and the successful development of the partnerships, highlighting them as key features. Interestingly, $90 \%$ of the partners have been members of the studied partnerships for more than one year (57\% between one and five years, $20 \%$ between five and ten, and 13\% for more than 10 years). This commitment can be interpreted as a medium to long term approach towards the sustainability of their communities, which for business partners is long considering that sustainability is usually not part of 
their core strategies and medium for partner organizations from the civil society that in general would have a closer relationship to sustainability. Partnerships are an opportunity for businesses to address public expectations, not-for-profits to be more efficient, and for organizations from the public sector to improve transparency $[55,56]$. Their commitments to local sustainability partnerships also refer to these.

With respect to local regulatory elements of context, it is important to highlight that although in these cases they play some role, the leaders of the partnerships highlighted that they always need to be revised particularly policies concerning the local environmental, and social and economic issues. Furthermore, regulatory elements may not happen in other jurisdictions where municipal authorities have a more limited power debilitating the potential engagement of partners in local sustainability partnerships and the success of the partnerships. Furthermore and beyond the logic of power dynamics, this also relates to the limitations of implementing macro sustainability strategies or guidelines at the micro-level, a failure that was seen with the implementation of the Millennium Development Goals [131] and that could certainly happen with the SDGs if local features such as cultural values are not considered in their implementation. This needs to be further explored. On the other hand, the lack of regulations at the national level playing a role in local sustainability partnerships shows a structural limitation, but also an opportunity. The limitation is that national authorities have not yet thought of sustainability with a local approach, which may translate into losing control over communities, but giving local authorities the chance of designing their sustainability strategies with a local flavour, with higher chances of success. As seen from the cultural-cognitive elements of context, Barcelona and Bristol have a very unique identity, so the local implementation of sustainability strategies designed at the national level would most likely not only be badly received, but also poorly implemented considering their particular local features. This is another dimension to be further assessed in the context of communities and countries more homogeneous.

Cultural-cognitive elements are the main enablers for both partnerships, highlighting the willingness of partners to act, the open participation of citizens in political decisionmaking, a public opinion enabling political leadership and advocacy, and recognitions that create awareness, expectations, and a sense of pride. Barcelona draws attention to working shoulder to shoulder with its partners, the relevance of trust-building and honesty, and the diversity of organizations and people who form $\mathrm{B}+\mathrm{S}$ as part of their customs, culture and history. Similarly, BGCP highlights the sense of place, civic memory, their history, building community resilience, and the existing coopetition with other communities as key elements of its cultural-cognitive pillar. The partnerships also highlight norms of participation as relevant, informal rules, with clear norms of participation and expectations as elements of their normative pillars [30]. While these features exist, others are required to be revised to contribute to the development of the partnerships. $\mathrm{B}+\mathrm{S}$ demands more resources of all kinds, i.e., financial, larger teams, time to engage with partners, and culture-changers, identifying also the need for policies to be implemented as institutional features at all levels (regulations-regulatory pillar, and informal rules-normative pillar). Interestingly, BGCP highlights the impact that the history of Bristol has on the partnership, particularly, its social structure founded on the slave trade, its social divisions, inequalities, and that sustainability is seen as an issue for the rich (customs, culture, and history—cultural—cognitive pillar), and the need to reduce inequalities and work towards integration and diversity (norms of behaviour, codes of conduct, and expectations-normative pillar). The capacity to push the boundaries of other communities and to communicate effectively among peers are also significant elements, representing the roles that leadership and communication structures play as normative and regulatory elements, respectively.

At the international level, it is not a surprise that cultural-cognitive elements are not present since these partnerships are locally focused; however, institutional logics based on globalization and the consideration of two communities inserted in the developed European realm would have suggested that the international sustainability agenda was taking a strong stance in these communities. Despite the purpose of the European Union 
of creating a common market of which the U.K. was part of since 1973 and Spain is since 1986 [132], the concept of a common Europe that is more about unity than identity [133] is also not represented in these partnerships. Similarly, the SDGs were expected to play a role as the most important agreement ever achieved among governments [134] with actors from diverse sectors engaged in their attainment, especially considering that these are European cities with huge international exposure. More than an issue for these cities, this result shows the poor sustainability approach of international organizations towards local sustainability. Conversely, it is interesting to see B $+\mathrm{S}$ and BGCP as isolated initiatives within their own countries where national (or international) features do not play significant roles in their development, something unexpected considering the crucial role of national institutional contexts in the construction of 'institutional thickness' [27,37]. It is these partnerships the ones influencing other communities on the development of sustainability initiatives. Perhaps in time, we will see their leadership role contributing to stronger national institutional contexts.

The institutional pillars proposed by Scott [30] help to classify the elements that allow the development of sustainability partnerships, although the approach does not differentiate the weight they could potentially have on their development. This exploratory research has gone one-step further identifying cultural-cognitive and normative elements as the main factors for local sustainability partnerships. Regulatory elements are certainly also relevant, but it seems that local features related to the history, ways of being, and expectations of society are much more important for sustainability partnerships. The engagement of organizations in them is based on trust and their long term commitments supported by public pressure on the one hand, but also by their own expectations as members of a community with sustainability needs that they all want to address collaboratively for their own good, highlighting the relevance of sense of place. This exploratory research shows that local culture and norms are strong features influencing the development of sustainability partnerships and the engagement of their partners.

From this analysis, an interesting difference can be seen between Scott's culturalcognitive and normative elements, and regulatory elements of context. The first two are locally embraced and subject to local particularities related to people, history, expectations and ways of being, all unique, naturally evolving in time and somehow commonly agreed, understood or locally accepted. Conversely, regulatory elements in this context are usually vertically imposed, sometimes brought in as successful experiences from other places, even designed by others without any connection to the locality. This disconnection seems to create a challenge for Scott's pillars as they do not connect to a place in a similar manner. From a contingency perspective, sustainability partnerships would adapt to the conditions presented by their contexts in order to develop and succeed, which makes sense as these are locally focused and the most relevant pillars are locally bounded. However, their contingency approaches also leave opportunities out of reach such as considering the framework proposed by the SDGs or other international initiatives such as the United National Global Compact or sustainability reporting for corporations, or the Covenant of Mayors as useful perspectives to consider to address their local challenges. These initiatives can be translated into regulatory elements with a local flavour expanding the approach proposed by Scott through his pillars and enhancing the chances of achieving local sustainable development.

The achievement of sustainable development at a local level is a certain and necessary challenge to consider. This article aims to contribute with a better understanding of the institutional contexts under which local sustainability partnerships are implemented and the roles they play towards sustainable cities. I hope that the findings and analysis presented here help other sustainability initiatives to successfully deal with institutional contexts so that their sustainability goals can be achieved. 


\section{Conclusions}

This research studies the partnerships' institutional contexts through Scott's [30] pillars at different levels, highlighting as well the need for associated activities and resources to provide stability and meaning to sustainability partnerships. B + S and BGCP were selected as successful partnerships because of their membership size, time partnering and sustainability progress, features explained mainly thanks to the cultural-cognitive and normative elements. Particularly relevant features from the inner contexts include political engagement, partners' commitment and willingness to contribute to the sustainability of their communities, as well as a sense of pride and the existence of informal rules from the outer contexts [6]. However, despite their relative success, the partnerships recognise that the existing institutional elements are not enough and more is needed for them to keep progressing. While some cultural-cognitive and normative elements are required to be revised, such as their historical constraints and burdens, as well as their norms of behaviour and informal rules, resources of different types and regulations and policies are also demanded. This research aims to contribute to the implementation of cross-sector sustainability initiatives through the identification of key institutional features at different scales thanks to the experience of two large and successful sustainability partnerships.

Funding: This research was funded by Athabasca University Associate Vice President Research Special Research Opportunities Fund.

Institutional Review Board Statement: The study was approved by Athabasca University Research Ethics Board (Ethics file number 23519 from 17 July 2020).

Informed Consent Statement: Informed consent was obtained from all subjects involved in the study.

Data Availability Statement: Data available on request due to restrictions.

Conflicts of Interest: The author declares no conflict of interest.

\section{References}

1. Ferraro, F.; Etzion, D.; Gehman, J. Tackling Grand Challenges Pragmatically: Robust Action Revisited. Organ. Stud. 2015, 36, 363-390. [CrossRef]

2. Crane, A.; Seitanidi, M.M. Social Partnerships and Responsible Business. What, Why and How? In Social Partnerships and Responsible Business. A Research Handbook; Seitanidi, M.M., Crane, A., Eds.; Routledge: London, UK, 2014; pp. 1-12.

3. Barroso-Méndez, M.J.; Galera-Casquet, C.; Seitanidi, M.M.; Valero-Amaro, V. Cross-Sector Social Partnership Success: A Process Perspective on the Role of Relational Factors. Eur. Manag. J. 2016, 34, 674-685. [CrossRef]

4. Waddock, S.A. A Typology of Social Partnership Organizations. Adm. Soc. 1991, 22, 480-515. [CrossRef]

5. Ordonez-Ponce, E.; Clarke, A.; Colbert, B.A. Collaborative Sustainable Business Models: Understanding Organizations Partnering for Community Sustainability. Bus. Soc. 2021, 60, 1174-1215. [CrossRef]

6. Dopson, S.; Fitzgerald, L.; Ferlie, E. Understanding Change and Innovation in Healthcare Settings: Reconceptualizing the Active Role of Context. J. Chang. Manag. 2008, 8, 213-231. [CrossRef]

7. Suddaby, R.; Elsbach, K.D.; Greenwood, R.; Meyer, J.W.; Zilber, T.B. Organizations and Their Institutional Environments-Bringing Meaning, Values, and Culture Back In: Introduction to the Special Research Forum. Acad. Manag. J. 2010, 53, 1234-1240. [CrossRef]

8. Lawrence, P.R.; Lorsch, J.W. Differentiation and Integration in Complex Organizations. Adm. Sci. Q. 1967, 12, 1-47. [CrossRef]

9. Fitzgerald, L.; Ferlie, E.; Wood, M.; Hawkins, C. Interlocking Interactions: The Diffusion of Innovations in Health Care. Hum. Relat. 2002, 55, 1429-1449. [CrossRef]

10. Buchanan, D.A.; Denyer, D.; Jaina, J.; Kelliher, C.; Moore, C.; Parry, E.; Pilbeam, C. How Do They Manage? A Qualitative Study of the Realities of Middle and Front-Line Management Work in Health Care. Health Serv. Deliv. Res. 2013, 1. [CrossRef]

11. Clarke, A.; Crane, A. Cross-Sector Partnerships for Systemic Change: Systematized Literature Review and Agenda for Further Research. J. Bus. Ethics 2018, 150, 303-313. [CrossRef]

12. Sun, X.; Clarke, A.; MacDonald, A. Implementing Community Sustainability Plans through Partnership: Examining the Relationship between Partnership Structural Features and Climate Change Mitigation Outcomes. Sustainability 2020, 12, 6172. [CrossRef]

13. Hesse, A.; Kreutzer, K.; Diehl, M.-R. Dynamics of Institutional Logics in a Cross-Sector Social Partnership: The Case of Refugee Integration in Germany. J. Bus. Ethics 2019, 159, 679-704. [CrossRef]

14. MacDonald, A.; Clarke, A.; Huang, L.; Seitanidi, M.M. Multi-Stakeholder Partnerships for Sustainability: A Resource-Based View of Partner Implementation Structure to Outcomes. Sustainability 2019, 11, 557. [CrossRef]

15. Ordonez-Ponce, E.; Clarke, A. Sustainability Cross-Sector Partnerships: The Strategic Role of Organizational Structures. Corp. Soc. Responsib. Environ. Manag. 2020, 27, 2122-2134. [CrossRef] 
16. Matos-Castaño, J.; Mahalingam, A.; Dewulf, G. Unpacking the Path-Dependent Process of Institutional Change for PPPs. Aust. J. Public Adm. 2014, 73, 47-66. [CrossRef]

17. Suárez, D.F.; Esparza, N. Institutional Change and Management of Public-Nonprofit Partnerships. Am. Rev. Public Adm. 2017, 47, 648-660. [CrossRef]

18. Ferri, L.M. The Influence of the Institutional Context on Sustainability Reporting. A Cross-National Analysis. Soc. Responsib. J. 2017, 13, 24-47. [CrossRef]

19. Clarke, A.; MacDonald, A. Outcomes to Partners in Multi-Stakeholder Cross-Sector Partnerships: A Resource-Based View. Bus. Soc. 2019, 58, 298-332. [CrossRef]

20. Branzei, O.; Le Ber, M. Theory-Method Interfaces in Cross-Sector Partnership Research. In Social Partnerships and Responsible Business; Seitanidi, M.M., Crane, A., Eds.; Routledge: London, UK, 2014; pp. 229-266.

21. Ordonez-Ponce, E.; Clarke, A.; MacDonald, A. Business Contributions to the Sustainable Development Goals through Community Sustainability Partnerships. Sustain. Account. Manag. Policy J. 2021. [CrossRef]

22. Moallemi, E.A.; Malekpour, S.; Hadjikakou, M.; Raven, R.; Szetey, K.; Moghadam, M.M.; Bandari, R.; Lester, R.; Bryan, B.A. Local Agenda 2030 for Sustainable Development. Lancet Planet. Health 2019, 3, e240-e241. [CrossRef]

23. Rok, A.; Kuhn, S. Local Sustainability 2012. Taking Stock and Moving Forward. Global Review; ICLEI-Local Governments for Sustainability: Bonn, Germany, 2012; pp. 1-87.

24. Ayuntamiento de Barcelona Compromiso Ciudadano por la Sostenibilidad 2012-2022. 2012. Available online: https://ajuntament. barcelona.cat/ecologiaurbana/sites/default/ files/CompromisoCiudadanoSostenibilidad.pdf (accessed on 23 August 2021).

25. Bristol Green Capital Partnership Our Future. A Vision for an Environmentally Sustainable Bristol 2019. 2019. Available online: https://bristolgreencapital.org/wp-content/uploads/2019/01/BGCP_Our-Future_2019-2.pdf (accessed on 23 August 2021).

26. Bristol Green Capital Partnership Bristol Green Capital Partnership. Available online: http://bristolgreencapital.org/ (accessed on 23 August 2021).

27. Amaeshi, K.; Adegbite, E. Corporate Social Responsibility in Challenging and Non-Enabling Institutional Contexts: Do Institutional Voids Matter? J. Bus. Ethics 2016, 134, 135-153. [CrossRef]

28. Kim, C.H.; Amaeshi, K.; Harris, S.; Suh, C.-J. CSR and the National Institutional Context: The Case of South Korea. J. Bus. Res. 2013, 66, 2581-2591. [CrossRef]

29. Kiss, A.N.; Danis, W.M. Country Institutional Context, Social Networks, and New Venture Internationalization Speed. Eur. Manag. J. 2008, 26, 388-399. [CrossRef]

30. Scott, W.R. Institutions and Organizations; Sage Publications: Thousand Oaks, CA, USA, 1995.

31. Schaltegger, S.; Hansen, E.G.; Lüdeke-Freund, F. Business Models for Sustainability: Origins, Present Research, and Future Avenues. Organ. Environ. 2016, 29, 3-10. [CrossRef]

32. Weick, K. The Social Psychology of Organizing; Addison-Wesley Publishing Company, Inc.: Reading, MA, USA, 1969.

33. Vurro, C.; Dacin, M.T.; Perrini, F. Institutional Antecedents of Partnering for Social Change: How Institutional Logics Shape Cross-Sector Partnerships. J. Bus. Ethics 2010, 94, 39-53. [CrossRef]

34. Ariztía, T.; Kleine, D.; Brightwell, M.d.G.S.L.; Agloni, N.; Afonso, R.; Bartholo, R. Ethical Consumption in Brazil and Chile: Institutional Contexts and Development Trajectories. J. Clean. Prod. 2014, 63, 84-92. [CrossRef]

35. Chakrabarty, S.; Bass, A.E. Institutionalizing Ethics in Institutional Voids: Building Positive Ethical Strength to Serve Women Microfinance Borrowers in Negative Contexts. J. Bus. Ethics 2014, 119, 529-542. [CrossRef]

36. Maes, V.; Guarido Filho, E.R.; Costa, M.C. Estratégias Organizacionais de Sustentabilidade e o Contexto Institucional: Implicações a Partir Do Discurso Da Mídia de Negócios. Organ. Em. Contexto 2018, 14, 93-121. [CrossRef]

37. McCarthy, J. Partnership, Collaborative Planning and Urban Regeneration; Ashgate Publishing Limited: Abingdon, OX, USA, 2007; ISBN 978-0-7546-1375-6.

38. Coluccia, D.; Fontana, S.; Solimene, S. Does Institutional Context Affect CSR Disclosure? A Study on Eurostoxx 50. Sustainability 2018, 10, 2823. [CrossRef]

39. Huq, F.A.; Stevenson, M. Implementing Socially Sustainable Practices in Challenging Institutional Contexts: Building Theory from Seven Developing Country Supplier Cases. J. Bus. Ethics 2020, 161, 415-442. [CrossRef]

40. Ortiz-de-Mandojana, N.; Aguilera-Caracuel, J.; Morales-Raya, M. Corporate Governance and Environmental Sustainability: The Moderating Role of the National Institutional Context. Corp. Soc. Responsib. Environ. Manag. 2016, 23, 150-164. [CrossRef]

41. Delmas, M.A. The Diffusion of Environmental Management Standards in Europe and the United States: An Institutional Perspective. Policy Sci. 2002, 35, 91-119. [CrossRef]

42. DiMaggio, P.J.; Powell, W.W. The Iron Cage Revisited: Institutional Isomorphism and Collective Rationality in Organizational Fields. Am. Sociol. Rev. 1983, 48, 147-160. [CrossRef]

43. Baïada-Hirèche, L.; Garmilis, G. Accounting Professionals' Ethical Judgment and the Institutional Disciplinary Context: A French-US Comparison. J. Bus. Ethics 2016, 139, 639-659. [CrossRef]

44. Yin, J.; Zhang, Y. Institutional Dynamics and Corporate Social Responsibility (CSR) in an Emerging Country Context: Evidence from China. J. Bus. Ethics 2012, 111, 301-316. [CrossRef]

45. Choi, Y.R.; Phan, P.H.; Choi, J. Formal Governance, Interfirm Coordination, and Performance in Partnerships: An Empirical Investigation of a Mediation Model. Eur. Manag. J. 2020, 38, 413-424. [CrossRef] 
46. Klijn, E.-H.; Teisman, G.R. Institutional and Strategic Barriers to Public-Private Partnership: An Analysis of Dutch Cases. Public Money Manag. 2003, 23, 137-146. [CrossRef]

47. Austin, J.E. Strategic Collaboration Between Nonprofits and Businesses. Nonprofit Volunt. Sect. Q. 2000, 29, 69-97. [CrossRef]

48. Alas, R.; Ennulo, J.; Tümpuu, L. Managerial Values in the Institutional Context. J. Bus. Ethics 2006, 65, 269-278. [CrossRef]

49. Adeleye, I.; Luiz, J.; Muthuri, J.; Amaeshi, K. Business Ethics in Africa: The Role of Institutional Context, Social Relevance, and Development Challenges. J. Bus. Ethics 2020, 161, 717-729. [CrossRef]

50. Melissen, F.; Mzembe, A.N.; Idemudia, U.; Novakovic, Y. Institutional Antecedents of the Corporate Social Responsibility Narrative in the Developing World Context: Implications for Sustainable Development. Bus. Strategy Environ. 2018, 27, 657-676. [CrossRef]

51. Kimura, T.; Nisjikawa, M. Ethical Leadership and Its Cultural and Institutional Context: An Empirical Study in Japan. J. Bus. Ethics 2018, 151, 707-724. [CrossRef]

52. Van Huijstee, M.; Francken, M.; Leroy, P. Partnerships for Sustainable Development: A Review of Current Literature. Environ. Sci. 2007, 4, 75-89. [CrossRef]

53. Gray, B. Collaborating. Finding Common Ground for Multiparty Problems; Jossey-Bass Inc.: San Francisco, CA, USA, 1989.

54. Glasbergen, P. Setting the Scene: The Partnership Paradigm in the Making. In Partnerships, Governance and Sustainable Development: Reflections on Theory and Practice; Glasbergen, P., Biermann, F., Mol, A.P.J., Eds.; Edward Elgar: Cheltenham, UK, 2007 ; pp. 1-25.

55. Gray, B.; Stites, J.P. Sustainability Through Partnerships; Network for Business Sustainability: London, ON, Canada, 2013.

56. Selsky, J.W.; Parker, B. Cross-Sector Partnerships to Address Social Issues: Challenges to Theory and Practice. J. Manag. 2005, 31, 849-873. [CrossRef]

57. Bryson, J.M.; Crosby, B.C.; Stone, M.M. The Design and Implementation of Cross-Sector Collaborations: Propositions from the Literature. Public Adm. Rev. 2006, 66, 44-55. [CrossRef]

58. Rühli, E.; Sachs, S.; Schmitt, R.; Schneider, T. Innovation in Multistakeholder Settings: The Case of a Wicked Issue in Health Care. J. Bus. Ethics 2017, 143, 289-305. [CrossRef]

59. Dresner, S. The Principles of Sustainability, 2nd ed.; Earthscan Publications Ltd.: London, UK, 2008; ISBN 978-1-84407-496-9.

60. Rangreji, L. "The Future We Want"-Reflections on the "Sustainable Development" Paradigm. Environ. Policy Law 2013, 43, 306-317.

61. United Nations. Agenda 21. In Proceedings of the United Nations Conference on Environment and Development (UNCED), Rio de Janeiro, Brazil, 3 June-14 June 1992.

62. ICLEI. Local Agenda 21 Survey: A Study of Responses by Local Authorities and Their National and International Associations to Agenda 21; ICLEI: New York, NY, USA, 1997. Available online: https:/ / digitallibrary.un.org/record/234344 (accessed on 23 August 2021).

63. Freeman, C.; Littlewood, S.; Whitney, D. Local Government and Emerging Models of Participation in the Local Agenda 21 Process. J. Environ. Plan. Manag. 1996, 39, 65-78. [CrossRef]

64. Roseland, M.; Spiliotopoulou, M. Converging Urban Agendas: Toward Healthy and Sustainable Communities. Soc. Sci. 2016, 5, 28. [CrossRef]

65. MacDonald, A.; Clarke, A.; Huang, L.; Roseland, M.; Seitanidi, M.M. Cross-Sector Partnerships (SDG \#17) as a Means of Achieving Sustainable Communities and Cities (SDG \#11). In Handbook of Sustainability Science and Research; Leal Filho, W., Ed.; Springer Publishing Company: New York, NY, USA, 2018.

66. Hall, P. Creative Cities and Economoc Development. Urban Stud. 2000, 37, 639-649. [CrossRef]

67. Hospers, G.-J. Creative Cities in Europe. Intereconomics 2003, 38, 260-269. [CrossRef]

68. Rodrigues, M.; Franco, M. Networks and Performance of Creative Cities: A Bibliometric Analysis. CityCult. Soc. 2020, 20. [CrossRef]

69. Batty, M.; Axhausen, K.W.; Giannotti, F.; Pozdnoukhov, A.; Bazzani, A.; Wachowicz, M.; Ouzounis, G.; Portugali, Y. Smart Cities of the Future. Eur. Phys. J. Spec. Top. 2012, 214, 481-518. [CrossRef]

70. Albino, V.; Berardi, U.; Dangelico, R.M. Smart Cities: Definitions, Dimensions, Performance, and Initiatives. J. Urban Technol. 2015, 22, 3-21. [CrossRef]

71. Bakici, T.; Almirall, E.; Wareham, J. A Smart City Initiative: The Case of Barcelona. J. Knowl. Econ. 2012, 2, 1-14.

72. Barrionuevo, J.M.; Berrone, P.; Ricart, J.E. Smart Cities, Sustainable Progress. IESE Insight 2012, 14, 50-57. [CrossRef]

73. Caragliu, A.; Del Bo, C.; Nijkamp, P. Smart Cities in Europe. J. Urban Technol. 2011, 18, 65-85. [CrossRef]

74. Ahvenniemi, H.; Huovila, A.; Pinto-Seppä, I.; Airaksinen, M. What Are the Differences Between Sustainable and Smart Cities? Cities 2017, 60, 234-245. [CrossRef]

75. Hiremath, R.B.; Balachandra, P.; Kumar, B.; Bansode, S.S.; Murali, J. Indicator-Based Urban Sustainability-A Review. Energy Sustain. Dev. 2013, 17, 555-563. [CrossRef]

76. Castells, M. Urban Sustainability in Information Age. City 2000, 4, 118-122. [CrossRef]

77. Roseland, M. Toward Sustainable Communities: Resources for Citizens and Their Governments, 2nd ed.; New Society Publishers: Gabriola Island, BC, Canada, 1998.

78. Creswell, J.W. Research Design: Qualitative, Quantitative, and Mixed Methods Approaches, 4th ed.; Sage Publications: Thousand Oaks, CA, USA, 2014.

79. Stake, R.E. The Art of Case Study Research; Sage Publications, Inc.: Thousand Oaks, CA, USA, 1995.

80. Merriam, S.B. Qualitative Research and Case Study Applications in Education; Jossey-Bass Inc.: San Francisco, CA, USA, 1998. 
81. Cho, J.Y.; Lee, E.-H. Reducing Confusion about Grounded Theory and Qualitative Content Analysis: Similarities and Differences. Qual. Rep. 2014, 19, 1-20.

82. Schilling, J. On the Pragmatics of Qualitative Assessment. Designing the Process for Content Analysis. Eur. J. Psychol. Assess. 2006, 22, 28-37. [CrossRef]

83. Yazan, B. Three Approaches to Case Study Methods in Education: Yin, Merriam, and Stake. Qual. Rep. 2015, 20, 134-152. [CrossRef]

84. Patton, M.Q. Qualitative Research E Evaluation Methods, 3rd ed.; Sage Publications: Thousand Oaks, CA, USA, 2002.

85. Creswell, J.W.; Plano Clark, C. Designing and Conducting Mixed Method Research, 2nd ed.; Sage Publications, Inc.: Thousand Oaks, CA, USA, 2011.

86. Spradley, J.P. The Ethnographic Interview; Waveland Press, Inc.: Long Grove, IL, USA, 1979.

87. Worley, C.G.; Mirvis, P.H. Studying Networks and Partnerships for Sustainability: Lessons Learned. In Building Networks and Partnerships. Organizing for Sustainable Effectiveness; Worley, C.G., Mirvis, P.H., Eds.; Emerald Group Publishing Limited: Bingley, UK, 2013; Volume 3, pp. 261-291, ISBN 978-1-78190-886-0.

88. Hawkins, C.V.; Krause, R.M.; Feiock, R.C.; Curley, C. Making Meaningful Commitments: Accounting for Variation in Cities' Investments of Staff and Fiscal Resources to Sustainability. Urban Stud. 2016, 53, 1902-1924. [CrossRef]

89. Instituto Nacional de Estadística. What Is the Population Of ... ? Available online: http://www.ine.es/en/welcome.shtml (accessed on 23 August 2021).

90. European Commission City of Barcelona's + Sustainable City Council Programme. GPP in Practice. 2016. Available online: https:/ / ec.europa.eu/environment/gpp/pdf/news_alert/Issue60_Case_Study121_Catering_Basel.pdf (accessed on 23 August 2021).

91. Hu, W. What New York Can Learn From Barcelona's 'Superblocks. The New York Times 2016. Available online: https:// barcelonarchitecturewalks.com/what-new-york-can-learn-from-barcelonas-superblocks/ (accessed on 23 August 2021).

92. ICLEI-Local Governments for Sustainability. Member in the Spotlight, Barcelona, Spain. Available online: http:/ /www.icleieurope.org/members/member-in-the-spotlight/archive/barcelona/ (accessed on 23 August 2021).

93. West of England Local Enterprise Partnership West of England Strategic Economic Plan 2015-2030. 2014. Available online: https:/ / www.lepnetwork.net/media/1101/west-of-england-sep.pdf (accessed on 23 August 2021).

94. Bell, H.; Croft, T.; Sear, Z. Citywide Review: The Story of Bristol's Green Capital Year; Bristol Green Capital Partnership: Bristol, UK, 2016.

95. Bristol City Council Bristol's Pioneering One City Approach Could Be In for a $1 \mathrm{~m}$ Euro Boost. Available online: https:/ / news. bristol.gov.uk/news/bristols-pioneering-one-city-approach-could-be-in-for-a-1m-euro-boost (accessed on 23 August 2021).

96. European Commission European Green Capital. Available online: http://ec.europa.eu/environment/europeangreencapital/ winning-cities/2015-bristol/index.html (accessed on 23 February 2017).

97. Hernández, A. Carta de Las Ciudades Europeas Hacia La Sostenibilidad. La Carta de Aalborg. Available online: http://habitat. aq.upm.es/indloc/aindloc_17.html (accessed on 12 February 2016).

98. Castiella, T.; Franquesa, T. A Participatory Process for Change. Available online: http://www.sostenibilitatbcn.cat/index.php/ angles/106-ag21-english/414-a21-agenda21-english-participatory-process (accessed on 23 August 2021).

99. Secretaría Barcelona + Sostenible Agenda 21 de Barcelona. Available online: http://www.sostenibilitatbcn.cat/index.php/castella (accessed on 12 February 2016).

100. Consejo Municipal de Medio Ambiente y Sostenibilidad El Compromiso Ciudadano por la Sostenibilidad [Agenda 21 BCN]. 2002. Available online: http:/ / www.publicacions.bcn.es/b_mm/abmm59/abmm_59.htm\#2 (accessed on 23 August 2021).

101. Departament d'Estadística i Difusió de Dades. Informes Estadístics. Característiques de La Població de Barcelona Segons El Padró Municipal; Ajuntament de Barcelona: Barcelona, Spain, 2019.

102. Barcelona Activa Barcelona Data Sheet 2018. Main Economic Indicators for the Barcelona Area 2018. Available online: https: //www.slideshare.net/barcelonactiva/barcelona-data-sheet-2018 (accessed on 23 August 2021).

103. Statistical Institute of Catalonia GDP per Inhabitant. Available online: https: / / www.idescat.cat/pub/?id=aec\&n=356\&lang=en (accessed on 23 August 2021).

104. Ajuntament de Barcelona Evolución de La Tasa de Paro En Barcelona y Otros Ámbitos Territoriales. Available online: https: / / www.bcn.cat/estadistica/castella/dades/ttreball/epa/epa/patu/evtatterr.htm (accessed on 23 August 2021).

105. Ajuntament de Barcelona Tasa de Riesgo de Pobreza En Barcelona y Otroa Ámbitos. Available online: https://www.bcn.cat/ estadistica/castella/dades/anuari/cap04/C0415050.htm (accessed on 23 August 2021).

106. KPMG. Global Cities Investment Monitor 2019. New Rankings, Trends and Criteria. 2019. Available online: https://medias. businessimmo.com/default/0002/46/145460/globalcitiesinvestmentmonitorweb.pdf (accessed on 23 August 2021).

107. fDi Magazine. FDi's European Cities and Regions of the Future 2018/19; The Financial Times Ltd.: London, UK, 2018.

108. Atomico. The State of European Tech 2018. 2018. Available online: https://2020.stateofeuropeantech.com/ (accessed on 23 August 2021).

109. The Economist Intelligence Unit Safe Cities Index 2017. Security in a Rapidly Urbanising World 2017. Available online: https: / / eiuperspectives.economist.com/infrastructure-cities/safe-cities-index-2017-security-rapidly-urbanising-world (accessed on 23 August 2021).

110. Arcadis Citizen Centric Cities. The Sustainable Cities Index 2018. 2018. Available online: https://www.arcadis.com/campaigns/ citizencentriccities/index.html (accessed on 23 August 2021).

111. 100 Resilient Cities Selected Cities. Available online: https://www.100resilientcities.org/cities/ (accessed on 23 August 2021). 
112. C40 Cities Barcelona. Membership Profile. Available online: https://www.c40.org/cities/barcelona (accessed on 23 August 2021).

113. Cuixart Tornos, M. Interview with Marta Cuixart Tornos from Barcelona + Sostenible 2019. Available online: http://www. pachelbel.eu/ZonaPublicaFiles/Marta_Cuixart_(English)F.pdf (accessed on 23 August 2021).

114. Cuixart Tornos, M. Barcelona's Citizen Commitment to Sustainability 2018. Available online: https:/ /www.youtube.com/watch? $\mathrm{v}=\mathrm{tqEsm} 9 \mathrm{WAlFw} \& \mathrm{t}=18 \mathrm{~s}$ (accessed on 23 August 2021).

115. Brownlee, E. History \& Archive. Available online: http:/ / bristolgreencapital.org/who-we-are/archive/ (accessed on 23 February 2017).

116. Bristol City Council The Population of Bristol. Available online: https://www.bristol.gov.uk/statistics-census-information/thepopulation-of-bristol (accessed on 23 August 2021).

117. Centre for Cities. Cities Outlook 2020. 2020. Available online: https://www.centreforcities.org/publication/cities-outlook-2020/ (accessed on 23 August 2021).

118. EY Beyond Brexit “Levelling Up" the UK 2020. Available online: https:/ / emeia.ey-vx.com/4838/138354/landing-pages/ey-ukregional-economic-forecast-february-2020.pdf (accessed on 23 August 2021).

119. Bristol City Council State of Bristol. Key Facts 2019. Available online: https://bristolresearchnetwork.wordpress.com/2019/10/ 30/state-of-bristol-key-facts-2019/ (accessed on 23 August 2021).

120. Pipe, E. Bristol's Economy Is Flourishing, but Prosperity Is Not Shared Among All. B24/7. 2018. Available online: https://www. bristol247.com/business/news-business/bristols-economy-is-flourishing-but-prosperity-is-not-shared-among-all/ (accessed on 23 August 2021).

121. University of Bristol Sustainability. Available online: http://www.bristol.ac.uk/city/bristol-is-famous-for/sustainability/ (accessed on 23 August 2021).

122. Arcadis. Sustainable Cities Mobility Index 2017. Bold Moves 2017. Available online: https://trid.trb.org/view/1489272 (accessed on 23 August 2021).

123. Dentchev, N.A.; Eiselein, P.; Kayaert, T. Social Responsibility within Brussels Municipalities: An Exploratory Study. In Corporate Social Responsibility; Business and Society 360; Emerald Group Publishing Limited: Bingley, UK, 2018; Volume 2, pp. 147-174.

124. Lizama-Pérez, F.; Piñar-Álvarez, M.; Ortega-Argueta, A.; Mesa-Jurado, M.A.; Sandoval-Caraveo, M.; Carrera-Hernández, A. Implementation and Performance of Agenda 21 for Local Governments in Mexico. Reg. Cohes. 2018, 8, 15-44. [CrossRef]

125. Kamaruddin, S.; Ahmad, P.; Alwee, N. Community Awareness on Environmental Management through Local Agenda 21 (LA21). Procedia Soc. Behav. Sci. 2016, 222, 726-737. [CrossRef]

126. Smith, T.W. Surveying Across Nations and Cultures. In Handbook of Survey Research; Marsden, P.V., Wright, J.D., Eds.; Emerald Group Publishing Limited: Bingley, UK, 2010; pp. 733-763.

127. Baptiste, E.J. Appendix 2: Translation Protocol 2003. Available online: https://www.cdc.gov/nchs/data/washington_group/ meeting5/WG5_Appendix2.pdf (accessed on 23 August 2021).

128. Harkness, J.A. Round 4 ESS Translation Strategies and Procedures 2008. Available online: http:/ / www.europeansocialsurvey. org/docs/round4/methods/ESS4_translation_guidelines.pdf (accessed on 23 August 2021).

129. Bristol City Council Bristol Quality of Life Survey 2018/19. 2019. Available online: https://www.bristol.gov.uk/documents/20 182/33896/Quality+of+Life+2018-19.pdf/9bda1ca1-d1d8-83d3-605f-28bffba17a8a (accessed on 23 August 2021).

130. Agnew, J. The United States in the World Economy; Cambridge University Press: Cambridge, MA, USA, 1987.

131. Adger, W.N.; Barnett, J.; Brown, K.; Marshall, N.; O’Brien, K. Cultural Dimensions of Climate Change Impacts and Adaptation. Nat. Clim. Chang. 2013, 3, 112-117. [CrossRef]

132. European Union The 27 Member Countries of the EU. Available online: https://europa.eu/european-union/about-eu/countries_ en\#tab-0-1 (accessed on 23 August 2021).

133. Stråth, B. A European Identity: To the Historical Limits of a Concept. Eur. J. Soc. Theory 2002, 5, 387-401. [CrossRef]

134. George, G.; Howard-Grenville, J.; Joshi, A.; Tihanyi, L. Understanding and Tackling Societal Grand Challenges Through Management Research. Acad. Manag. J. 2016, 59, 1880-1895. [CrossRef] 